\title{
COMMERCIAL SEXUAL EXPLOITATION OF CHILDREN: AN EFFORT OF HANDLING AND LEGAL PROTECTION
}

\author{
Devi Rahayu; Syamsul Fatoni \\ Faculty of Law, University of Trunojoyo Madura \\ E-mail: rahayudevi78@yahoo.com
}

\begin{abstract}
This article aimed to analyze a significant efforts to protect and prevent a commercially sexual exploitation of children (hereinafter abbreviated to CSEC). There are many child trafficking in border areas and cities as happened in Surabaya, which are identified as sending, transit and destination cities. The research type used is the juridically empirical study, namely the effectiveness research of regulations enforcement on the child protection. Primary data obtained from victim experience , such as: children and the family, law enforcement, government, and companion Non Governmental Organization (hereinafter abbreviated to NGO). Data collection techniques carried out by the interview method and Focus Discussion Group. The results showed that the commercial sexual exploitation of children is an act of human trafficking because the objectives of the sexual action is to obtain money or other goods with the children, sex service users, liaison and related parties. The highest educated victims of the commercially Sexual Exploitation of Children (CSEC) consist of high school students and child having an economically inadequate condition, broken home family, and the influence of uncontrolled social media.
\end{abstract}

Keywords: sexual exploitation; child protection

\section{INTRODUCTION}

Women are the susceptible parties to becoming victims of violence having a result in physical, psychological, economic and sexual impacts. This is an important matter due to the impact felt by the victim if they do not get a treatment which will be felt throughout her life. In the case of children, they determine the future existence of nation. The Government concerns the importance of the child, therefore the provisions specifically regulated in the Child Protection Law Number 23 of 2002 and Law Number 35 of 2014 on the Amendment of Law Number 23 of 2002 on the Child Protection. The provisions stipulate a such guarantee for the children rights protections as well as sanctions for those who commit crimes against children.

Basically, the children rights are to play, but in reality there are children who are forced to work. In its progress towards the worst forms of exploitative and harmful to the growth and development of physical, mental, moral, social and intellectual children. In 1998 the issue of child trafficking for prostitution, child domestic servitude

$330 \quad$ Yustisia Volume 8 Number 2 (May-August 2019) C Commercial Sexual Exploitation ...

(C)2019; This is an Open Acces Research distributed under the term of the Creative Commons Attribution Licencee (https://Creativecommons.org/licences/by/4.0), which permits unrestricted use, distribution, and reproduction in any medium, provided the original works is properly cited. 
and other worst forms of child labor (Utami, 2006: 14). Regulations regarding the worst forms of child labor are regulated in ILO Convention 182 on the prohibition of the worst forms of child labor (Nunung Purwanti, 201 7: 469), one of which is economic and/or sexual exploitation of children. Sexual exploitation is the use of children for the purpose of sexual contentment in the form of money or anything other than money between children and masher man also getting the advantage from the child trafficking sexually (Bagong Suyanto, 2003: p 80). Whereas the Commercially Sexual Exploitation of Children (CSEC) is the use of children for sexual contentment to get a benefit from the trafficking of child sexuality. The forms of CSEC according to the Convention on the Rights of the Child Article 34 stating: (1) child prostitution; (2) child sexual trafficking; (3) using children for pornography.

In Indonesia, there are many trafficking of women in border areas of the neighboring countries, especially in Singapore and Malaysia, such as Riau (Batam and surrounding areas), Medan and West Kalimantan. Trafficking in women are also often occured in big cities, such as Jakarta, Surabaya, and Semarang. In fact, even in small cities, it is practically occured in tourism areas (Irwanto, 1999: 20). In 2003, a significant research conducted by ILO-IPEC estimated the number of commercial sex workers (CSWs) under the age of 18 years old, which were divided into major cities in Indonesia, such as: in Jakarta, the average number of victims approximately 1,244 children, the averane number of victims approximately 2,511 children in Bandung, the average number of victims approximately 520 children in Yogyakarta and the average number of victims approximately 4,990 children in Surabaya (KPI, 2007: 5 ), and the average number of victims approximately 1,623 children in Semarang (Bagong Suyanto, 2003: 80). Data from ECPAT in 2017 included 404 CSEC victims, consist of $16 \%$ in West Java, 12\% in East Java and 8\% in Riau (ecpatindonesia.org, accessed on January 2, 2018).

Commercial sexual exploitation of children in Surabaya is rife. This happens because the uniqueness of Surabaya is identified as the sending, transit and destination city for trafficking of women and children. Child trafficking that occurred in Surabaya as destination city for trafficking, mainly for prostitution or commercial sexual exploitation, was found quite a lot because in Surabaya there were 22 sites / locations of prostitution (KPI East Java, 2007: 7). Previously the government had closed down several other official localizations as happened in "Dolly". The legal basis for the closure of such localization is the Local Regulation Number 7 of 1999 on the Prohibition of Using Building or Place for Sexual Misconduct and Enchantment To Perform Sacrilegious Actions in the Municipality of Level II Surabaya. The closure of localization in Surabaya considered by many to be successful because in reality is the existence of localization has been closed, the absence of unrest during the 
closure, their persuasive attempts before closing and their empowerment for postclosure pimps and prostitutes.

The closure has 2 (two) positive and negative impacts. The positive impact provides a job training and providing venture capital, therefore they have business in their hometown. Another positive impact is the minimization of the practice of prostitution. Meanwhile, the negative impact, closure of localization does not mean that the problem of prostitution which has been addressed comprehensively, because displaced CSWS will potentially find other localization sites or even carry out prostitution practices in disguise. They will continue to practice prostitution in places that are far from the reach of the government such as in people homes, karaoke place, cafes and hotels. This makes it difficult to control and to record and treat diseases caused by sexual prostitution, therefore CSWS who have contracted the HIV virus can not be traced and have the potential to spread the virus.

The present the government and the authorities have difficulty in taking precautions due to a sexual exploitation are veiled and have exploited online media. Data from the Surabaya Police, there are several cases in 2015 mentioning children who were victims of exploitation in the past few months became pimps for their school friends. The process of exploitation is carried out with online media without meeting and meeting directly in hotels, or meeting in cafes and karaoke entertainment venues. They have become actors so that they are subject to criminal sanctions, this is certainly different when they become direct victims get assistance from the government or NGOs. This is certainly very worrying because the child prostitution transaction process is carried out in public places and with safer media.

These data indicate that CSEC issues are important to study. This reality condition is in contradiction with what is explained in Article 15 point of Law Number 35 of 2014 on The Child Protection, which states that each child whose parental rights are the parent, guardian or other party who has parental rights, then these children are entitled to protection from exploitation behavior, both economic exploitation and sexual exploitation by parties deemed to benefit. Protection and response efforts that have been undertaken by a local governments, law enforcement officers and the companion / NGO has found pattern or network of cooperation in addressing cases of commercial sexual exploitation. Have regulatory norms related to child protection been effective in the field in dealing with CSEC?

\section{RESEARCH METHODS}

This research applied empirically juridical approach, because it wanted to analyze the implementation of the law or the enforcement of law system (Freidman, 1977). The use of empirically or sociologically legal research is study of legal effectiveness 
(Soerjono Soekanto, 2010: 51). Research on legal effectiveness is intended to examine the symptoms of situation, personal behavior, and group behavior to obtain information about the cause of symptom. This research is research that aims for factfinding which then proceed to problem-findingthen lead to the problem-identification then to problem solution (Soerjono Soekanto, 2010: 10). This research was conducted in the city of Surabaya, which is the capital of East Java Province. The next reason for determining the city of Surabaya is because this city is the area of origin / sender as well as the destination / receiver of ESKA cases.

\section{RESEARCH RESULTS AND DISCUSSION}

\section{A. Understanding of The Sexual Exploitation in Children}

On this article, the concept of children based on the limitations used in the 1989 Convention on the Rights of the Child that children are those who are under 18 years old. These limits are universal due to the convention is a reference or basis for all UN member states that ratifying the convention, including Indonesia. The convention regulates the minimum standards of a country in guaranteeing children rights.

According to the manual on the handling of the sexually exploited children from the Ministry of Social Affairs, sexual exploitation is the use of minors for sexual acts with compensation in the form of money or non-money whose parties are child victims, users of sex services, connecting parties or other parties who benefit from sexually exploiting children. The forms of CSEC according to the Convention on the Rights of the Child Article 34 which states: (1) child prostitution; (2) child trafficking for sexual purposes; (3) child pornography.

According to the Protocol to Prevent, Eradicate and Providing Penalties for Human Trafficking, especially children and women, article 3, the definition of trafficking of Children for Sexual Purposes is "the recruitment, transportation, transfer, harboring or receipt of a child for the purpose of exploitation, child prostitution or other forms of sexual exploitation."

In research on CSEC, there are three concepts that must be clarified, namely the concept of trafficking of girls, violence (violence atmi nbitse), and children. These three concepts of a frame (frame) creating this research as a whole. Therefore, the concepts of CSEC, violence, and children are explained one by one.

Hull stated that the act of an exploit or trafficking of women have started since the time before independence, the time when the king as supreme leader in kingdom located on the island of Java at that time a king was considered as usual if he had more than one wife, even still have concubines. At that time the ordinary people or the middle class downward would be happy if their daughter 
was wanted by the king, so they were sold by the family. This was done so that the people could increase their social status (Hull et al, 2005: 2).

While in the time before having independence or when it was colonized, women trafficking also have occurred. This happened to fulfill the desires of the soldiers and Europeans. Another thing that is also the reason for women trafficking when it was not allowed the marriages between Asians and Europeans (prohibition of marriage different races) The relationship between the different races is illegal act. In addition, there was trafficking between Indonesian women to Europeans.

Women and children trafficking during the Japanese occupation in Indonesia was even more pathetic, because they were used by Japanese soldiers to satisfy their desires. These women and children were taken from their villages or hometowns with the lure of getting decent jobs and getting schools in the other city or in Tokyo. In fact women were forced to serve the passions of the Japanese army in a sustainable manner.

The practice of using women and children for sexual purposes is more due to responding to various external factors that cause the emergence of child prostitution. Children recruited for child trafficking syndicates are seen as commodities in the sex recreation market to fulfill deviant sexual desires. This is often responded by certain parents with various supporting conditions and considered as a chance to get money easily by selling their children to pimps or brokers. Especially for female traffickers, this is a golden opportunity to reap huge profits. Especially if these children are still virgins, the profit can make a bundle.

Trafficking in women, including children, is a form of violence occured due to the absence of the balanced relationship between men and women. In the context of the use of children to buy and sell relations occur under the bottom of the social structure of the position dominated by adults. In this case the perpetrator in material and psychological position controls the victim or has dominant position over the victim. In trafficking, the victim is in lower position and has indeed been planned to need the perpetrator either to certain networks (to trafficking institutions for women) and individuals, to related parties. The condition of victims is regulated always requiring individual perpetrators to get security and fulfill their economic needs.

Trafficking in women has actually been going on for a long time and has occurred in various places. Because the trade takes place over time, the concept of that also shifts from time to time. CSEC consists of human elements which include actors, consumers, and victims on one side, and technical elements including an exploitation, transfer, transport and boundaries. Trafficking or trafficking is used to term the act of trafficking in persons. This phenomenon 
of human trafficking emerged since 1949, namely since the signing of the Convention on Traffic in Persons.It is starting to grow as the number of reports about the occurrence of acts of trafficking in women on the signing of the Beijing Platform of Action which continued with the Convention on The Elimination of All Forms of Discrimination Against Women (CEDAW) and the dyadic option by Indonesia in Law Number 7 of 1984 on the Elimination of All Forms Women Discrimination and establishment of GAATW (Global Alliance Against Traffic in Women) in Thailand in 1994 (Women's Solidarity, 2000: 24).

Law Number 21 of 2002 on The Combating Trafficking in Persons, trafficking definition is act of recruiting, transport, accommodating, move or receive people through threat that done recruitment, transportation, storage, delivery, removal or receive someone with threats of violence, using violence, kidnapped, imprisoned, falsify identity, defraud, misappropriate with violence or the unbalanced position, ensnared by debt or procure a person who has control in order to be approved by the, giving payments or benefits to achieve the consent of a person having control over another person, made in one country and between countries with the purpose of exploiting or actions which could result in people being exploited. (Heny Nuraeny, 2012: 98) In the context of trafficking, whether or not there is agreement from another person in control or from the victim is not a crime that does not negate. This means that even with the consent of the victim, someone who is a trafficker can still be convicted. This is because victims who are usually children in vulnerable positions are under the authority of others so that children cannot give consent or because of the victim's ignorance because they are still in the category of children.

The exclusion of a person legally because the lack of capacity to give or receive conscious consent from child victims has implications that it has implications for the release from legal responsibility for the actions or negligence that he did. In the case of children usually get pressure, coercion, threats of violence will automatically cancel the conscious consent. (Heny Nuraeny, 2012: 23)

Commercial sexual exploitation of children is a form of trafficking in persons, because the purpose of sexual acts is to obtain monetary or non-monetary rewards whose parties consist of children, users of sexual services, liaison and other parties who benefit from utilizing child sexuality for sale. Trafficking of women who are still in the category of children for sexual activity in Surabaya is a social phenomenon that is quite warning because victims are under pressure and are made to always have a high dependency on female trafficking actors. In general, they only get a small income (25-60 percent) from the tariff of serving consumers (KPI, 2007: 7). 


\section{B. The Children Victims Condition of The Commercially Sexual Exploitation}

Based on the data obtained, it appears that the most recent CSEC education was SMP for CSEC by $27 \%$, then CSEC with SD education at ESKA reached $24 \%$, another thing to note is that CSEC is still in high school level with a percentage of $14 \%$. Based on these data, conclusions can be drawn regarding educational backgrounds, from any educational background, to being able to still go to school. The threat of a child who will become a CSEC victim is still high, this is based on a description of the latest level of education CSEC who have an average low education.

Regarding the background of the victim's family, the majority of CSEC data came from poor families by $38 \%$, followed by CSEC from broken home families by $23 \%$ and also from families in general by $6 \%$. Based on this information, it can be stated that the dominant background of CSEC comes from poor families, then CSEC comes from broken home families and what must be considered is that CSEC also comes from a number of families in general $(6 \%)$. Then how is the categorization of families from CSEC that emerged based on the findings of this study. The following table categorizes the background of CSEC families, namely poor families, broken families and families in general.

Table 1

CSEC Family Categorization

\begin{tabular}{|c|c|c|}
\hline Poor family & Broken family & Family in general \\
\hline $\begin{array}{l}\text { 1. Low parent education } \\
\text { 2. Not earning/earning less } \\
\text { than } 100 \text { thousand per } \\
\text { month } \\
\text { 3. Children not attending } \\
\text { school/dropping out of } \\
\text { school }\end{array}$ & $\begin{array}{l}\text { 1. There is domestic } \\
\text { violence } \\
\text { 2. There is divorce, } \\
\text { neglect of the family } \\
\text { 3. Poor parents/family } \\
\text { attention }\end{array}$ & $\begin{array}{l}\text { 1. Parental/family } \\
\text { attention is not } \\
\text { appropriate to } \\
\text { the child growth } \\
\text { and development } \\
\text { (unbalanced) } \\
\text { 2. Childrenaccess to } \\
\text { information and } \\
\text { entertainment is } \\
\text { easy }\end{array}$ \\
\hline
\end{tabular}

Based on the table that poor families have been defined, based on the research findings, the family whose parents have lower education (unfinished compulsory education of 9 years), family does not has income or income of less 
than USD 1.000,000 per month and CSEC is droped out from school. Whereas for the definition of broken home family is CSEC originating from family where domestic violence occurs, divorce occurs, neglect of the family and parents or family attention is lacking. Related to CSEC coming from families in general are CSECs that get the attention of parents or family not in accordance with the child growth and development and CSEC access to information and entertainment is easy.

Furthermore, it will be explained the causes and driving factors of CSEC, according to this research it appears that the cause of CSEC is promiscuity (24\%), then many CSECs are trafficked as much as $21 \%$ and then followed by CSEC caused by economic crush (14\%) and CSEC were 9\% victims of Domestic Violence. Based on these illustrations, it can be described that the majority of CSEC victims are caused by promiscuity, trafficking or economic trafficking. Based on the results of the FGD the factors that caused CSEC victims were: family factors, economic factors, social factors and social media. The family factor begins with the child feeling uncomfortable at home because parents are not attentive. This is because his parents often "bicker" and eventually his parents split up. Children become stressed and consider themselves unnoticed by their parents. This broken home family is one of the reasons children become victims of sexual exploitation. Family factors are also related to social factors and social media. Because it does not get the attention and comfort at home, the child will trust his friends more. Initially economic factors are often considered the main factors, but the reality of the background of the victims of the economic situation that is capable. What is often used as an economic reason is related to the need for luxury goods such as cellphones, gadgets and laptops. Nowadays children spend more time together with their friends. Social factors and social media are now important factors that are driving factors. If friend does one particular thing, then that will usually be done by another friend. From the narration of several children who become victims, they become victims because they are persuaded by their friends. In addition, because they want to have electronic devices like the same cellphone as their friends, the children become victims (Missy, 2018). Nowadays friendship is the dominant factor of children becoming victims of exploitation.

This study also described that the most trafficking perpetrators were $42 \%$ of brokers, followed by her boyfriends who became traffickers by $27 \%$, friends also had the opportunity to become traffickers by $15 \%$, and also her mother's friend ESKA by $12 \%$ and aunts, sisters, neighbors, fathers with percentage of $4 \%$ of traffickers each. Percentage of age of CSEC victims for the first time, with CSEC being the majority of victims (29\%) aged 16 years, followed by CSEC data for 
the first time being victims aged 17 years $(25 \%)$ and $15 \%$ of CSEC the first time being 15 years old. There was also the first CSEC victim who was 18 years old (14\%), CSEC aged 13 years by $10 \%$ and CSEC aged 14 years by $7 \%$. Therefore, it can be assessed that the majority of CSECs ( $86 \%)$ are under 17 years old. The children becoming CSEC victims caused by these factors as follows: (a) The existence of seduction and material lure in the form of money or expensive items such as cell phones, (b) There are acts of fraud and false promises, (c) There is coercion and intimidation both physically and psychologically.

\section{Technology advancement in cases of commercial sexual exploitation}

Online prostitution comes from two words, each of which can stand alone namely prostitution and online. Prostitution comes from the Dutch language, prostitutie, and in English, prostitution, which means prostitution. Prostitution is the same term as prostitution. according to Soerjono Soekanto, Prostitution can be interpreted as a job that is surrendering to people who are willing to give money in return for sexual acts. Prostitution is the provision of sexual services carried out by men or women to get money or satisfaction (Subaidah Ratna Juwita, 2016: 150).

As information technology developed rapidly, those involved in prostitution make use of this technology. Online prostitution also increase transaction rates among the culprit. this costly rates in online prostitution occurred because the perpetrators were those who labeled the artist, therefore it also contributed to the expensive rates for one date (Republika.co.id, accessed on May 11, 2015). This is like the case of Keyko (a pimp) who was handled by the Surabaya District Court. The teenage victims of prostitution consist of students and college students. They are undergoing prostitution because their families are unable, they do it because they are driven by lifestyle needs, such as wanting to wear the latest models of clothing or the latest gadgets. To get it they are trapped in prostitution (Widodo, 2011: 135). According to the case handled by WCC Palembang, teenagers who were trapped in prostitution were initially given the lure of various lifestyle facilities that they saw on television. It is also justified from the exposure of the companion at the embun shelter for victims of CSEC are restricted in using social media, because they take advantage of facebook and whatsapp to interact. The victims became victims because of the lure of getting the latest gadgets. Furthermore there were cases of online prostitution in Jakarta in 2012, which placed advertisements on the internet (www.tv7.online. com, accessed on December 25, 2012).

In the case of Keyko, it was proven to violate Article 506 of the Criminal Code concerning pimps, Article 296 of the Criminal Code concerning sexual 
abuse and Article 2 paragraph (1) of the Law on the Elimination of Trafficking in Persons. In the second case, article 506 of the Criminal Code, article 2 paragraph (1) of the Elimination of Trafficking in Persons and article 27 paragraph (1) of Law No. 11 of 2008 on The Electronic Information and Transactions (hereinafter named as ITE Law). Trafficking in Women and Children can be distinguished in the two cases is that in the second case using ITE Law article 27 paragraph (1) which regulates the prohibition of anyone without the right to distribute, transmit, or act so that information utilizing digital media or digital documents containing conflicting substances with naughtiness (Widodo, 2011: 135-137). In addition to the provisions of article 27 paragraph (1), it can also be based on the provisions of article 45 paragraph (1) of the ITE Law, each person who is in accordance with the elements of article 27 paragraph (1) which states that "... imposed with the longest imprisonment of 6 years and / or imposed maximum fine of $1,000,000,000 \ldots$ ", Basing on article 2 paragraph (1) of the Act on the Elimination of Trafficking in Persons indeed imposes more severe criminal sanctions than Article 45 paragraph (1) of ITE Law, which is subject to the shortest sanctions of 3 years and the longest 15 years. As for the imposition of fines, the regulation in article 45 paragraph (1) of the ITE Law is higher in number.

Users of online prostitution services are basically 'common people' and capable for responsible. Criminal liability towards prostitution service users is felt to require in-depth analysis. The analysis of criminal responsibility in theory explains that criminal responsibility is imposed on person if the person has committed criminal act. According to Moelyatno, "a person will not be asked to be criminally liable if that person has not committed a crime. (Moelyatno, 1987: 155). This means that a person will only be held criminally responsible if he has previously committed a crime. In the context of the legislation, it is also said that the presence or absence of a criminal is determined by statutory regulations, which are interpreted that there is no criminal liability without the rule of law that governs it first (Chairul Huda, 2011: 20-21). Prostitution service users cannot be convicted because the aforementioned elements have explained the weaknesses of the existing criminal law.

The authorities, in this case, the government seems to allow acts of prostitution. It is said to be indecisive due to the regulation regarding online prostitution criminal acts does not regulate the provisions regarding criminal sanctions for users of commercial sex services, so that users of online prostitution services can not be criminally accounted for, and those who use sex worker services. Future legal thinking or ius constituendum: the law aspired by the association of life and the state, but has not yet become a rule in the form of laws or other regulations, namely the RKUHP has not yet regulated criminal 
matters against prostitution service users. In Chapter XVI regarding the Criminal Acts of $R K U H P$, it has not yet been regulated. Thought about the need for rules governing prostitution especially for the users of his services is a strong basis because these acts of reality occur in people's lives, thus the existence of law, especially criminal, is expected to regulate it (Subadah ratna Juwita, 2016: 156). Arrangements for users can at least provide a deterrent effect because prostitution occurs because of the interaction between two parties, namely users of prostitution services and prostitution actors. The absence of sanctions for users of commercial sex services is also a form of community discrimination against women, because in these conditions only women are mistaken and the term CSW is used while men as users do not have the term Commercial Sex Users. In terms of normative Indonesia has ratified CEDAW with Law Number 7 of 1984 on The Ratification of the Convention Regarding the Elimination of All Forms of Discrimination against Women.

In previous exposure, it has been explained regarding factors causing children to become victims of CSEC, namely family, economic factor, relationships, and social media. In this millennial era there is a shift in the factors that cause if during this time the economic factor is considered as the main factor, the economy is not currently the main factor. Social factors and social media are now more likely to be a contributing factor, even more so in family conditions that pay less attention to children.

The existence of social media such as Facebook, Instagram, Twitter is a social network that is easily accessed by all parties, including children. This social media is misused by some parties to commit crimes. Children who are victims usually get acquainted through social media, then after a while they will meet, and when they meet, children will usually be very easy to be targeted as victims of sex exploitation crimes by perpetrators (then Muhammad Wahyu, 2013: 8). This was also conveyed during the FGD with several parties stating that social media factors are now often used as a way for certain people to look for victims (LPPM UTM, FGD, July 11, 2018).

\section{Legal Protection of Children Victims of Commercial Sexual Exploitation}

The concept of legal protection relates to the concept of the rule of law, this is because the concept of legal protection is one of the characteristics of the form of the rule of law that is related to the guarantee of fulfillment of human rights. The concept of a 19th-century rule of law was introduced originally by Julius Stahl. Shortly afterwards there was the concept of the rule of law initiated by AV Dicey, who was born in the Anglo Saxon legal system, Dicey put forward the elements of the Rule of Law as follows (Dian Astri, 2009: 54): 
a. Supremacy of law; Absence of Arbitrary Power, in the sense that people can only be punished if they against the law.

b. Equality Before The law. This proposition applies both to people who are not domiciled and also to those who have a position.

c. Human right guarantee in regulations (in other countries) by the Constitution and judicial decisions.

Indonesia is a state of law (Rechtstaat) aimed to ensure the welfare of each of its citizens, this also includes the protection of children rights which are also human rights. This is also in line with the adoption of the concept of Welfare State by Indonesia, a concept that requires prosperity / welfare for its citizens. So the government is required to be active in order to realize the objectives of the Welfare State concept, one of which is the policies that the government can realize in a statutory regulation. The aim is to provide legal protection for citizens without discrimination. The state of community reality that the government cannot avoid is the problem of poverty. This problem is increasing in number which also significantly impacts the increase in the number of child laborers. Working children is a polemic for every country. Children here need special protection from every element of government and non-government.

Legal protection has the meaning of behavior or legal action carried out by the government by giving up the rights and obligations of legal subjects and implemented based on the applicable law in Indonesia.

Legal protection arises because of legal relationship. Legal relations (Rechtbetrekking) are interactions between legal subjects that have legal relevance or have legal consequences (the arising of rights and obligations). The child who is employed must be given special protection from the government. A child who is forced to work is a form of neglect of children rights, because at the same time there will be disregard for the rights that must be accepted by them. As we know, the right to get education, play, access to health and others. This situation makes child labor a category that requires Special Protection (Children In Need Of Special Protection) which demands serious handling from parents, families, communities and related groups and the government as policy makers.

In context of Indonesia, Pancasila which is ideology of the state becomes the basis in determining the principle of legal protection. The existence of guarantees and protection of human rights is a source of the principle of legal protection in government actions. This is because historically in the western world where there are guarantees and legal protections starting from the limitations and things that must be done by society and government. (Philipus M Hadjon, 2007: 32). Thus legal protection is the protection of the nature of human position and guarantees 
of human rights possessed by the legal subjects of a country based on protection from arbitrary behavior. In this case, there are two forms of legal protection for the people, namely preventive protection in the form of legislation that specifically regulates children who are victims of exploitation and repressively is the existence of law or sanctions provided by the law.

Special protection based on point 1 point 15 of Law Number 23 of 2002 on The child protection, namely protection provided to children in emergency situations, children are faced with the law of children from minority and isolated groups, children are exploited economically and or sexually, children trafficked children, victims of abuse of narcotics, alcohol, psychotropic substances, and other addictive substances.

In the provisions of article 1 points 15 and 15a of Law Number 35 of 2014 on The Child Protection which states (15) there is special protection received by children if there is something dangerous. In the context of children who are victims of commercial sexual exploitation, special protection must be given (Ahmad Hafid Jimy, 2016: 16). Furthermore, Article 59 paragraph (2) i, said special protection in children can be given to children victims of sexual crimes. Specifically, the forms of protection stipulated in article $60 \mathrm{a}$ are: reproductive health education, social rehabilitation, psychosocial assistance and provision of protection and assistance at the time of the examination.

Provisions of article $15 \mathrm{f}$ stating that: "every child has the right to get protection from sexual crimes". While the provisions of article 21 paragraphs (4) and (5) there are obligations for regional governments to organize child protection and build child-friendly cities. This has been done by the Surabaya city government, Article 76 i, everyone is prohibited from exploiting economically and / or sexually against children. While the criminal threat is regulated in article 88 , which can be imposed with a maximum jail sentence of 10 years and maximum fine of 200,000,000.

Overall, the Law has regulated criminal sanctions for child sexual exploitation perpetrators. In the implementation, the police and prosecutors as legal apparatus have implemented the provisions as well, because the police will make special efforts so that victims can relate the events comfortably and accompany them to inspire victim courage. The prosecutors said they would process it quickly related to cases of child sexual exploitation. However, for the first time, if the perpetrators are children, for the first time there is still guidance from the authorities and make children victims. However, if the commercialization is carried out a second time and so on, the authorities will impose strict sanctions and treat them as perpetrators (FGD LPPM UTM, 2018). 
In the field of labor, the protection of workers according to Iman Soepomo in Asikin is divided into three types: (Zainal Asikin, 1993: 76)

1. Economic protection, which is protection effort related to ways to give adequate income to meet the needs of workers and their family members. Related also to workers who cannot work because of things outside their wishes.

2. Social protection, which is associated with the protection of society where having directions the workers can acquire and promote human social life as a fairy life as average human as well as community members and family members. This is realized in the form of health protection for workers and group guarantees and safeguarding the right to join the organization.

3. Technical protection, which is a maintenance effort against worker -related to the ways to avoid accident at work that can result from working equipment or materials processed by company. This is realized in the form of work safety and security.

Legal protection for child labor is also regulated in the Manpower Law. Article 68 of Law Number 13 of 2003 stipulates that employers are prohibited from employing children. Protection against prohibition of children from being employed is intended so that children can obtain their rights to develop their personality and to obtain education because children are a generation of the nation. However, this provision is excluded in Article 69 paragraph (1) that for children aged 13 (thirteen) up to 15 (fifteen) years can be employed in work that is not strenuous and as long as it does not inhibit the development of the child physically, psychologically and physically social. Article 69 paragraph (2) provides provisions for employers who employ children in light work as referred to in paragraph (1) must meet the requirements. In article 74, children are prohibited from working in the worst types of work in the form of: slavery, using children for prostitution and pornography and narcotics and work that endangers the health and morals of children.

In the context of CSEC, children have been victims of sexual exploitation, which clearly results in physical and psychological developmental delays in children development. It could even aim for prostitution and certainly endanger the health and morals of children. Children are exploited economically, experience threats and physical violence, psychological pressure, experience certain diseases and damage children morality. Therefore the existence of CSEC victims has clearly violated the provisions of employment $n$. 


\section{E. Law Enforcement of Child Protection in Handling Commercially Sexual Exploitation}

Surabaya is the capital of East Javaprovince, therefore it used as barometer in every government and community organization activity. The reality is that victims of commercial sexual exploitation in Surabaya. As for the reason children become victims of commercially sexual exploitation due to they are victims of rape, lifestyle and the treatment of parents. The perpetrators themselves are friends, girlfriends and parents meaning the perpetrators here are people known to the victims. Comprehensive handling of victims physically, psychologically, socially and economically is needed so that children can be separated from acts of sexual exploitation.

Based on local regulation Number 6 of 2011 on the Implementation of Child Protection, the city of Surabaya is child friendly city. There is system that guarantees the rights of children are integrated in commitment and services by the government, the public and private sectors. There is children forum that plans activities that guarantee the fulfillment of childrenrights. (Zulkarnain, 2018: 40). According to Article 3 of Local Regulation Number 6 of 2011 on the Implementation of Child Protection, the municipal government, regional people, who have family relations and who have children are obliged to carry out child care. Article 15 (1) b the regional government and the community are obliged to provide social welfare against exploited victims who are used to get money or sexually. The forms of services are: health, education, mental and spiritual social guidance, social rehabilitation, assistance, empowerment, social assistance, legal assistance and reintegration of children in the family. In addition, the government is obliged to provide safe houses and a forum for children participation. The handling of child victims of sexual exploitation is indeed cross-sectorial, because it deals with parents, the government, law enforcement officials, NGOs and the community. For the government itself, this child handling problem is related to the health, education, social, PP Police Unit and DP5A agencies. Synergy between all elements is absolutely necessary so that children really get the protection of their rights. This is in accordance with the Child Protection Act, Article 25 paragraph (2) community obligations and responsibilities in protecting children are carried out by involving social organizations, academics and observers of children. Furthermore, in Article 55 paragraph (3) the government can work together with various parties related to the care of abandoned children.

In the FGD activities it was found that all parties involved in handling child victims of sexual exploitation had established good communication between them. This means that when there are cases, the government, law enforcement 
and NGOs will help each other to deal with them. For example, if a child is accompanied by an NGO, he or she will receive assistance from NGOs, the DP5A and the police. The post mortem process is carried out in a hospital where nurses are very cooperative, at the time of the inspection the police in the PPT unit will accompany you kindly and if needed psychological services the DP5A will assist. After filing is polarized, all parties will continue to oversee the case at the prosecutor's office, the trial and until there is a judicial decision. Shelter services have been provided by the local government, besides that if it takes a long time the government will leave victims in safe houses owned by NGOs. The relationship established between NGOs and the government according to Philip Eldrigde NGOs has an important network to play a role in sharing information, providing legal access and access in government, the media and formatting opinions. NGOs also have the ability to lobby for an issue that they are concerned about in the field (Amalia Ayang, 2017: 114). The entire handling process is expected to be able to provide services that can provide victims' rights in this case children.

Overall the efforts that have been made by various parties, namely the government and also accompanying NGOs in the efforts to deal with and prevent CSEC are:

\section{Table 2}

\section{Results of FGD Activities}

\begin{tabular}{|c|c|c|c|}
\hline Program Done & Barriers & Plan & Intervention \\
\hline $\begin{array}{l}\text { Surabaya Big City } \\
\text { Police } \\
\text { 1. Handling child } \\
\text { trafficking cases for } \\
\text { CSEC } \\
\text { 2. Presenting religious } \\
\text { counselors and } \\
\text { counselors for } \\
\text { victims } \\
\text { Education Agency } \\
\text { 3. Full day school } \\
\text { Ministry of Religion } \\
\text { Surabaya } \\
\text { 4. Penamas } \\
\text { 5. Mapenda } \\
\text { 6. Handling of res- } \\
\text { ponses (children) }\end{array}$ & $\begin{array}{l}\text { Surabaya Big City } \\
\text { Police } \\
\text { 1. Perspectives that } \\
\text { "children are } \\
\text { c o mm odities", } \\
\text { "children belong to } \\
\text { parents" } \\
\text { 2. Law does not } \\
\text { resolve (includes } \\
\text { family, awareness, } \\
\text { etc.) } \\
\text { 3. Lesser than optimal } \\
\text { knowledge of God, } \\
\text { economics and } \\
\text { education }\end{array}$ & $\begin{array}{l}\text { 1. Parenting for parents } \\
\text { (not only in school, } \\
\text { but in parents } \\
\text { whose children are } \\
\text { also not / not yet in } \\
\text { school) } \\
\text { 2. Adoption of infants } \\
\text { and children of } \\
\text { CSEC victims } \\
\text { 3. There needs to } \\
\text { be a model of } \\
\text { accompaniment } \\
\text { and rehabilitation } \\
\text { to completion. } \\
\text { Because the shelter } \\
\text { holds } 2 \text { weeks (and } \\
\text { although it can be } \\
\text { extended) including }\end{array}$ & $\begin{array}{l}\text { Parents: } \\
\text { 1. Parenting/Paren- } \\
\text { ting Education } \\
\text { (Education Agency) } \\
\text { 2. Through the PKK in } \\
\text { the community to } \\
\text { reach parents } \\
\text { 3. The availability } \\
\text { of information is } \\
\text { not only normative } \\
\text { by the ministry of } \\
\text { religion }\end{array}$ \\
\hline
\end{tabular}




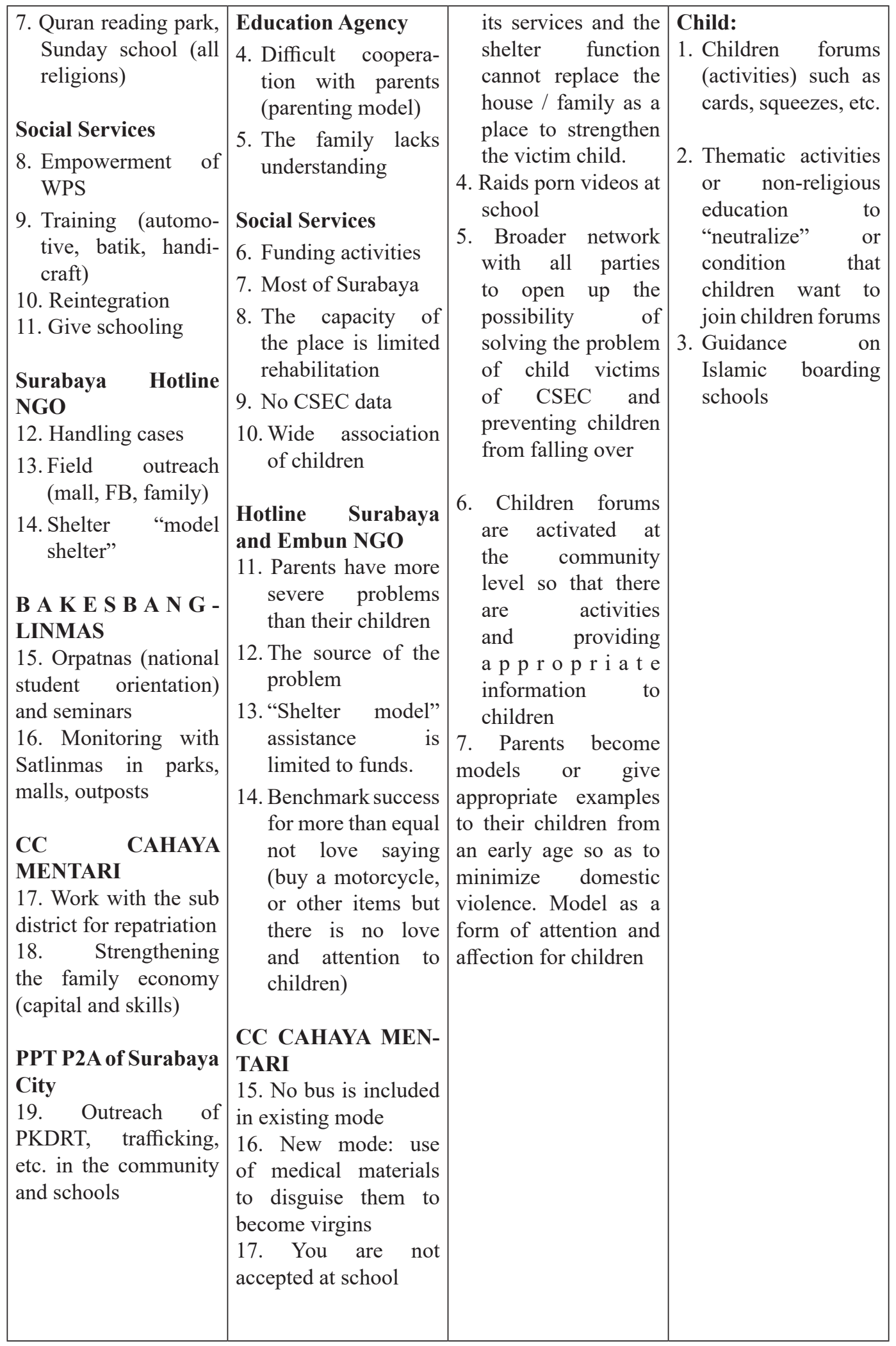




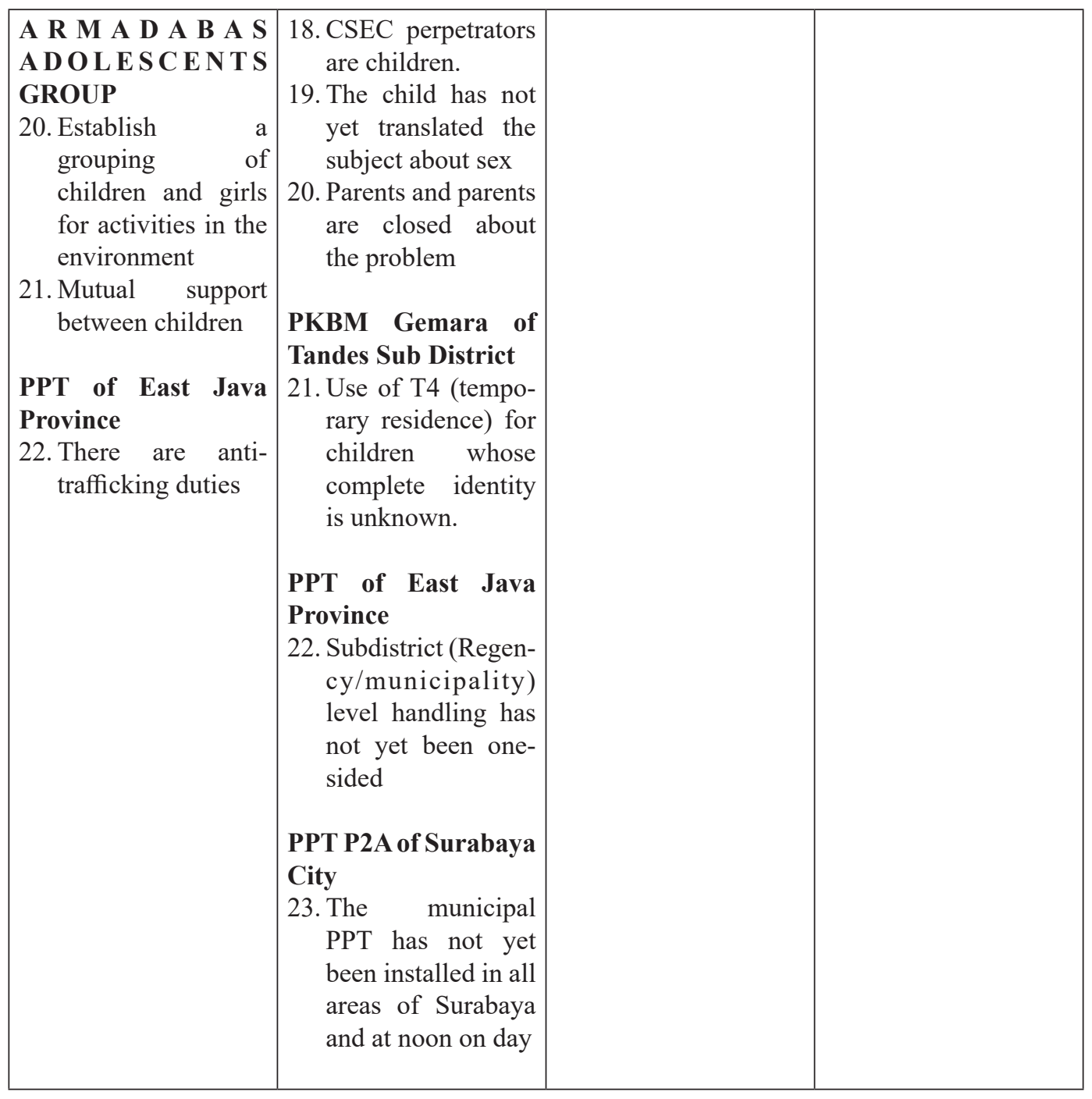

Source: FGD Results, UTM LPPM, Handling and protection of Children Victims of Sexual Exploitation, Surabaya, 11 July 2018

between institutions or networks of all parties, including the government, law enforcement officials, assisting NGOs, victims and their families and the community has been done quite well. Even for certain cases where CSEC victims want to continue their education, the local government will facilitate it so that victims can still obtain their educational rights. Even collaboration guided by the private sector / corporation has been carried out to empower victims and so victims can be independent in their lives. However, there are also problems in the handling of CSEC, which are related to the time limit in handling victims in safe houses. Shelter owned by the government has a time limit in accommodating victims, so if the time is over then the victim will be handed over to the accompanying NGO. 
Based on ECPAT's explanation in the matter of law enforcement on child protection, there are still a number of problems related to handling cases of sexual exploitation of children, namely: the judicial process that takes a long time, many court decisions that do not fulfill a sense of justice for victims and ultimately do not prioritize the interests victims specifically related to the rights of victims such as the right to get recovery, rehabilitation and restitution (icjr. or.id, March 22, 2017).

Based on Government Regulation Number 43 of 2017 on the Implementation of Children Being Restitution for Victims of Crime, Article 2 states "that every child victim of a criminal offense is entitled to receive restitution. Thus children who are victims of CSEC certainly have the right to get restitution. During this time the country in response to sexual violence still focuses on punishment for the perpetrators, to bring a new kind of punishment in the form of chemical castration for perpetrators of criminal sanctions and the provision of the death penalty. Focusing on victims by providing guarantees of assistance, recovery and restitution should be a point of pressure when assisting victims of CSEC cases (Seno Wibowo Gumbira, 2018: 102). Sexual violence has different characteristics from other crimes. Often there are judgments and stigmas in the community that corner the victim and her family members. There are $96 \%$ of victims of cases of sexual violence who do not report to the authorities due to the stigma and victimization of victims. There is a guarantee for the protection of victims and members of their families, whether legal proceedings or not, by all parties handling CSEC cases. Every victim of sexual violence who has not or has not yet processed their case is legally entitled to compensation, medical assistance or psychosocial and psychological rehabilitation through LPSK. By focusing on assistance, rehabilitation and food compensation is expected to focus on the rights of victims and not only focus on severe penalties for perpetrators (icjr. or.id., July 14, 2018)

Verdict of Supreme Court Number 937 / PidB / 2008 / PN.Sby stating that defendant who employ women and children as prostitutes. In this case women who were victims of sexual exploitation were 6 people, of which 5 were still in the category of children because they were 16 years old. In its decision the judge only indicted the suspect based on article 2 paragraph (1) in conjunction with article 17 of Law Number 21 of 2007 on the Termination of the Criminal Act of Trafficking in Persons. Convicted the defendant Heriyanto with 8-year prison sentence and a fine of Rp. 120,000,000 (one hundred and twenty million rupiah).

While in the Cibinong court decision Number 301 / Pid.sus / 2015 / PN.Cbi stating that defendants: Wulansari, Yanti, Guntur, Iman, Awin and Ria Indah, all of whom were conspirators who had their respective roles in illegal recruitment 
for sexual purposes.. They recruited the victim's child by promising his mother to be employed at a restaurant in Jakarta. It turns out that Jakarta is employed as a GoGo dancer and accompanies guests at KingKros for drinks from 7:00 a.m. until the morning. The victim works for 3 days because she can escape and return to her parents' home. At as such cases the perpetrators on behalf Wulansari, Yanti and Guntur convicted under article 2, paragraph (10 of Law Number 21 of 2007 on The Eradication of Tranfficikng in Person in conjunction with Article 55 paragraph (1) of the Penal Code with imprisonment of 4 years and a fine of Rp 120,000.000, - (one hundred and twenty million rupiah) and charged the defendant to pay a restitution / compensation fee to the victim in the amount of Rp.15,000,000.- (fifteen million rupiahs) The judge's basic consideration in dropping restitution on the defendant which is based on article 2 of Law Number 21 of 2007 on The Eradication of Tranfficikng in Person which implies a prison sentence accompanied by a fine. While the basis of the public prosecutor demanding restitution is article 48 paragraph (2) of Law Number 21 of 2007 on The Eradication of Tranfficikng in Person Law (Supriyadi, 2016: 28-30)

According to these two court decisions, there are different things regarding the existence of restitution demands and do not depend on the demands of the public prosecutor. Supporting NGOs and the community certainly become a controlling tool for law enforcement officials in implementing regulations that favor the victims in the case of children as CSEC victims, so the provision of restitution to victims of sexual crimes is important to be given because the impact of these actions has a mental and psychological impact that requires rehabilitation processes a long time so that the certainty of the time depends on the victim and the case.

\section{CLOSING}

\section{A. Conclusion}

The conclusions that can be drawn in this paper are:

1. Children sexual exploitation for commercial purposes is an act to use child for the sexually contenment in order to receive gifts in the form money or other. It occurs with the parties of the children, beneficiaries of sexual services, liaison and others who benefit from child sexual purchase. Commercially sexual exploitation of children is a form of trafficking in persons, because the purpose of sexual acts is carried out to obtain profits in the form of money and non-money with the same parties as the sexual exploitation of children and aims to benefit from such actions. 
2. The situation of CSEC victims were junior, elementary and high school education. The family situation of the family, in conditions of economic insufficiency and broken home. Factors that cause person to become CSEC victim are family, economic, social or environmental factors and social media. The perpetrators are scalpers, girlfriends and other people who are closed to the victim. The majority of CSECs are less than 17 years old. The modus operandi of children becoming CSEC victims is: (a) The existence of seduction and material lure in the form of money or expensive items such as mobilephones, (b) There are acts of fraud and false promises, (c) There is coercion and intimidation both physically and psychologically.

3. The use of online media for prostitution and trafficking activities has been regulated in the Electronic Information and Transaction Law and the Pornography Law. Social media is one of the factors causing CSEC. Article 1 points 15 and 15a of Law Number 35 of 2014 on The Child Protection which states (15) the existence of special protection received by children if there is something dangerous. In the context of children who are victims of commercially sexual exploitation have special protection must be given. Rule 15a is an understanding of violence which includes sexual violence. Furthermore, Article 59 paragraph (2) i, said special protection in children can be given to children victims of sexual crimes. Specifically, the forms of protection stipulated in article 60 are: reproductive health education, social rehabilitation, psychosocial assistance, and provision of protection and assistance at the time of the examination.

4. Based on Local Regulation Number 6 of 2011 on the Implementation of the Protection of the Child states that the city of Surabaya is a child-friendly city where there are systems that ensure childrenrights that are integrated in commitment and services by the government, the public and private sectors. There is a children forum that plans activities that guarantee the fulfillment of childrenrights. Coordination between institutions or networks of all parties, including the government, law enforcement officials, assisting NGOs, victims and their families and the community has been done as well. Even for certain cases of CSEC victims the government facilitates educational needs so that victims can still obtain their educational rights. Even cooperation with the private sector / corporation to empower victims.

\section{B. Suggestions}

1. Advocate women about the negative effect of The CSEC and provide prevention tips so they do not become victims; 
2. Prevent CSEC by providing children with a sense of security in the family environment and providing stock of religious understanding and character to children so that if there is a problem in the family the child still remembers God.

3. Parents are required to provide an understanding of the positive and negative impacts of online media use and criminal consequences if they abuse social media.

4. There is a requirement for mutual understanding to jointly bear all the victim needs while the victim is in the shelter of the accompanying NGO.

\section{ACKNOWLEDGMENTS}

The research was funded and supported by the Ministry of Research, Technology, and Higher Education of 2017-2018

\section{BIBLIOGRAPHY:}

\section{Books:}

Azikin, Zainal. (1993). Fundamentals of Labor Law. Jakarta: Radja Grafindo Persada.

Hull et.all.. (2005). Prostitution in Indonesia History and Development. Jakarta: Sinar Harapan Pustaka.

Huda, Chairul. (2011). From No Crime Without Error Towards No Criminal Accountability Without Error. Jakarta: Kencana Predya media.

Irwanto. (1999). Problems faced by child laborers. Yogyakarta: Obor.

Indonesian Women Coalition. (2007). CSEC in Surabaya, East Java Regional Surabaya. KPI.

Moelyatno. (1987). Principles of Criminal Law. Jakarta: Bina Aksara.

M. Hadjon, Philipus. (2007). Legal Protection for the Indonesian People, Printing M2 Print (special edition):.

Nuraeny, 2012, Criminal of Human Trafficking in Theory and Practice. Surabaya: Sinar Grafika.

Suyanto, Bagong. (2013). Child Social Problems. Surabaya: Kencana Prenada Media. Soekanto, Soerjono. (2010). Introduction to Legal Research. Jakarta: UI Press. 
Women's Solidarity. (2000). Human Rights in Practice Guidelines Against Trafficking of Women and Children. Jakarta.

Widodo. (2011). Criminal Law in the field of Information Technology. Yogyakarta: Aswaja Pressindo.

Widodo, Supriyadi. (2016). Handling cases of commercial sexual exploitation of children in Indonesia. Jakarta: ECPAT.

\section{Journals:}

Ahmad Hafid Jimy. (2016). Legal Protection of Children Victims of Commercial Sexual Exploitation, Thesis, Surabaya State University.

Amalia Ayang Sabrina. (2017). Government and Non Governmental Organization Organization on Protection Child labor in East Java, Indonesia, Atlantis Press, Advanced in Social Sciences Education and Humanities Research, Volume 167.

Diar Astri. (2009). Legal Protection of Child Labor Under Law Number 13 of 2003 on The Employment. Sriwijaya University: A Final Project.

Nunung Purwanti. (2007). Social Protection For Child Labor, Atlantis Press, Advanced in Social Sciences Education and Humanities Research, Volume 81.

Seno Wibowo Gumbira. (2018). The Implications Of Expanding The Authority Of The Pretrial Post-Verdict Judicial Review Of The Constitutional Court In Deciding Whether It Is A Valid Determination Of The Suspect Against Law Enforcement And The Protection Of The Rights Of The Suspect. Yustisia Jurnal Hukum, Volume 7 Number 1

Subaidah Ratna Juwita. (2016). Reformulation of Criminal Liability in Online Prostitution Perpetrator: A Normative Study. Journal of Socio-Cultural Dynamics, Volume 18, Number 1.

Utami. (2006). Handling Child Problems in Malang, Legality, Legal Scientific Journal, Volume XII, Number 2.

Zulkarnain, Potential Analysis of Building Child's Region to Accelerating The Implementation of the Convention on The Rights of the Child in Informal Education, Atlantis Press, Advanced in Social Sciences Education and Humanities Research, Volume 128.

\section{Websites:}

Republika.co.id, Technological Progress also Encourages the Birth of Online Prostitution, May 11, 2015, https:/www.republika.co.id/berita/nasional/ umum/15/05/11/no71sv-kemajuan-teknologi-ikut-dorong-lahirnya-prostitusionline,Diakses pada 3 November 2018. 
ECPAT. (2017). Notes: 404 Children Become CSEC Victims, 2 January 2018, http://ecpatindonesia.org/berita/catat-ecpat-indonesia-tahun-2017-404-anakmenjadi-korban-eska/ accessed on Monday October 15, 2018.

ICJR, Handling ESKA Cases in Indonesia: Learning from Experiences in Handling ESKA Cases in Indonesia, March 22, 2017, http://icjr.or.id/penanganan-kasuseksploitasi-seksual-komersial-anak-eska-di-indonesia-belajar-dari-pengalaman penanganan-perkara-kasus-kasus-eska-di-indonesia/ accessed on Sunday May 262019.

ICJR, Case of Sexual Violence in Children: ICJR Regards The Government Focus Still Punishment, 10 January 2018, http://icjr.or.id/kasus-kekerasan-seksualpada-anak-icjr-sayangkan-fokus-pemerintah-masih-penghukuman/ Accessed on Sunday My 262019.

Then Muhammad Wahyu, Legal Protection of Children Victims of Commercial Sexual Exploitation, Thesis, University of Brawijaya, 2013.

LPPM UTM, FGD Handling and protection of child victims of sexual exploitation, Surabaya, 11 July 2018. 